\title{
Effect of Polarisation Functions on to Errors of Ab-initio Calculations for Ibuprofen
}

\author{
Nil E. Binbay ${ }^{1 *}$, Veysel Binbay ${ }^{2}$ \\ ${ }^{1}$ Department of Electronics, Vocational School, Dicle University, Turkey (ORCID: 0000-0002-2488-0378) \\ 2 Department of Physics, Institute of Natural Science, Dicle University, Turkey (ORCID: 0000-0002-1018-5438)
}

(This publication has been presented orally at HORA congress.)

(First received 1 August 2019 and in final form 24 October 2019)

(DOI: $10.31590 /$ ejosat.637854)

ATIF/REFERENCE: Binbay, N. E. \& Binbay, V. (2019). Effect of Polarisation Functions on to Errors of Ab-initio Calculations for Ibuprofen. European Journal of Science and Technology, (Special Issue), 233-241.

\begin{abstract}
Computational algorithms, which aimed to solve quantum mechanical equations for molecules, usually produces more errors about the bonds which involves Hydrogens, than the others. Actually this fact is more or less expected, due to unique properties of Hydrogen atoms, such as carrying just single electron for making bonds with other atoms.

Computational approaches, unlike the analogue solutions, usually neglect many parameters, under some reasonable assumptions of course, to reduce complexity of quantum systems to some computable ranges. Actually all practical quantum computations can be considered as managing the "neglecting process", by keeping the balance between reduced complexity and acceptable correctness.

Polarisation is one of those parameters that usually neglected, for quantum molecular computations about molecules.

On the other hand, Hydrogen has a serious capability of being strongly polarised, due to possibility of existence of semi or fully naked protons, when it constructs a bond structure.

Within this point of view, it is needed to analyse the effect of adding polarisation functions, on to calculation errors, especially for hydrogens, by hoping to reduce big calculation errors about them.

Here, we added polarisation functions to optimisation calculations of ibuprofen molecule, to see the effect of polarisation functions to the errors of computed bond lengths. We have compared the results to X-RAY data.

Finally it is concluded that, more polarisation function reduces the calculation errors, but it is not worth to increased computational costs.
\end{abstract}

Keywords: Ibuprofen, DFT, Polarisation, Optimisation.

\section{Ab-initio Hesaplamalardaki Hatalar Üzerine Polarizasyon Fonksiyonlarının İbuprofen İçin Etkisi}

$\ddot{\mathbf{O z}}$

Moleküller için kuantum mekanik denklemleri çözmeyi hedefleyen hesaplamalı kimya algoritmaları, genellikle Hidrojen atomunun dahil olduğu bağlar için, diğerlerinden daha fazla hata üretir. Bu durum, aslında, hidrojen atomunun, diğer atomlarla bağ yapmak üzere sadece tek bir elektrona sahip olması gibi tekil özellikleri göz önüne alındığında, az çok beklenen bir durumdur.

Kompütasyonel yaklaşımlar, analog çözümlerden farklı olarak, kuantum sistemlerin karmaşıklık düzeyini, hesaplanabilir seviyelere indirgemek için, uygun varsayımlar altında, genellikle bir çok parametreyi ihmal ederler. Aslında nümerik kuantum yaklaşımlarının tamamı, "karmaşıklı̆̆ı azaltma" ve "kabul edilebilir doğruluk seviyesinde kalma" arasındaki dengeyi koruyarak ihmal etme seçeneklerini yönetmek süreci olarak değerlendirilebilir. 
Polarizasyon, moleküller içinkuantum mekanik hesaplamaları için, bu çerçevede genellikle ihmal edilen bir parametredir. Öte yandan hidrojen atomunun, başka bir atomla bağ yaptığında, yarı ya da tam çıplak bir proton olarak bulunma ihtimali dolayısıyla, ciddi bir polarize olma kapasitesi vardır.

Bu bakış açısıyla, özellikle hidrojen atomunun dahil olduğu bağlarla ilgili büyük hata oranlarını azaltacağı umularak, hesaplamalara daha fazla polarizasyon fonksiyonları eklemenin bütün bağ türleri için hesaplama hataları üzerine etkisinin araştırılmasına ihtiyaç vardır. Bu çalışmada, hesaplanan bağ uzunluklarına ilişkin hatalar üzerindeki etkisini incelemek üzere, ibuprofen molekülünün optimizasyonu için yapılan hesaplamalara fazladan polarizasyon fonksiyonları eklenmiştir. Sonuçlar X-RAY datalarıyla kıyaslanmıştır. Nihayetinde, daha fazla polarizasyon fonksiyonu eklemenin gerçekten de hesaplama hatalarını azalttı̆̆ hesaplama zamanındaki artışa değecek düzeyde olmadığı yargısına varılmıştır.

Anahtar Kelimeler: Ibuprofen, DFT, Polarizasyon, Optimizasyon.

\section{Introduction}

Computational methods have become an indispensable tool for contemporary chemistry over last decades, doe to significant improvements about calculation abilities of computers. They have become applicable over many application areas, even for proteins and enzymes, those contains thousands of atoms.

Unlike the analogue equation solving methods, numerical alghoritms, inevitably includes neglections. It comes from basic necessity of numerical approaches. Polarisation effect is usually neglected in a typical molecular computation.

On the other hand, it is a known fact that, molecular computations, usually produces more errors about the bonds about Hydrogene atoms, than the others (Boese, 2015; Ireta, Neugebauer, \& Scheffler, 2004; Rozas, 2007) . Particularly within this work, the calculated bond length error for $\mathrm{C}-\mathrm{C}$ bonds, for instance, falls within the range $2-3 \%$ range, but for $\mathrm{C}-\mathrm{H}$ bonds it is found within $14-16 \%$ range.

If we consider the unique properties of Hydrogene atoms, such as having only a single electron to construct a bond structure, it is understood that, Hydrogene atom has a serious potential to be being polarised. In this case, the major cause of big calculation errors about Hydrogene bonds, might be considered as the polarisation itself. Hence, it is needed to investigate the effect of adding polarisation functions to calculatet bond length errors, to check if this is true.

Here, it is studied and reported, the effect of polarisation functions on to the calculated bond length errors, for ibuprofen molecule.

\section{Material and Method}

The ibuprofen molecule was optimised by using a general ab initio quantum chemistry package GAMESS (the General Atomic and Molecular Electronic Structure System)( Schmidt et al., 1993; Dykstra, Frenking, \& Kim, 2011). The DFT (Density Functional Theory)(Hohenberg \& Kohn, 1964) was employed for ab-initio calculations of ibuprofen molecule. The hybrid Becke, three-parameter, Lee-Yang-Parr, using coulomb attenuating method (CAM-B3LYP) (Yanai, Tew, \& Handy, 2004) was used as exchange correlation functional for DFT calculations. The basis set that used for calculation was the SBKJ (Stevens, Bash, Krauss, Jasien) valance with ECP (Effective Core Potential)(Stevens, Krauss, Basch, \& Jasien, 1992). Ibuprofen molecule was optimized several times, by using the same hardware, the same software, the exact same starting configuration, and the same parameter set, except that the added polarisation functions. Ibuprofen was optimised three times; first, with no polarisation function, second, with a polarisation function, third, with three polarisation functions.

\section{Results and Discussion}

The optimized molecular structure of ibuprofen has given in Figure-1; the calculated molecular electrostatic potential of ibuprofen has given in Figure-2; the calculated totoal electron densitiy of ibuprofen molecule has given in Figure-3. 


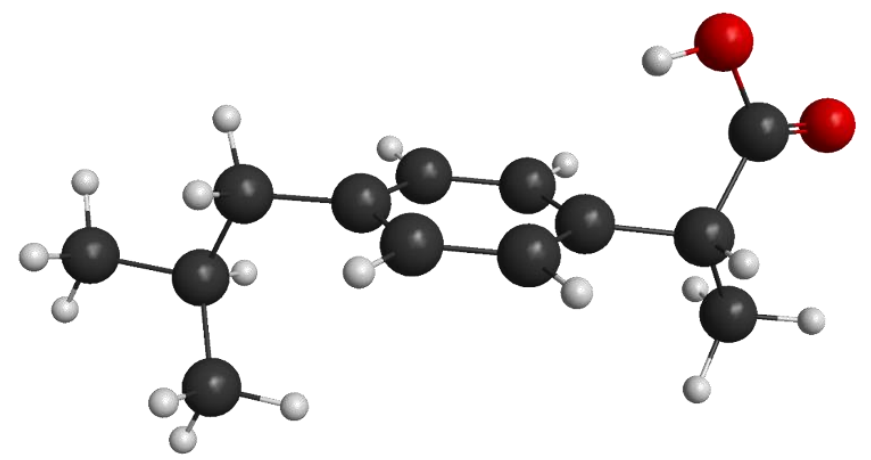

Figure 1 The optimized structure of ibuprofen.

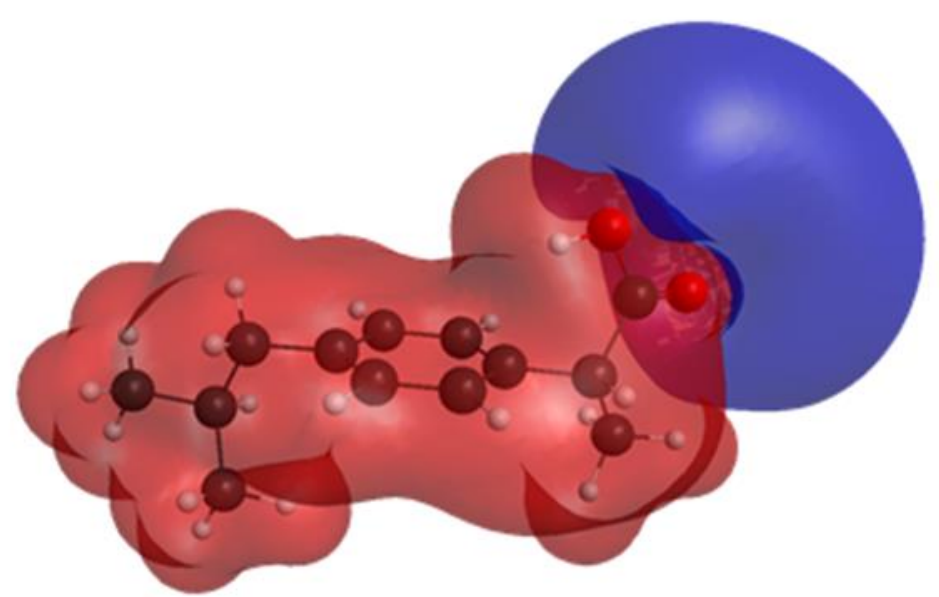

Figure 2 The calculated electrostatic potential of ibuprofen.

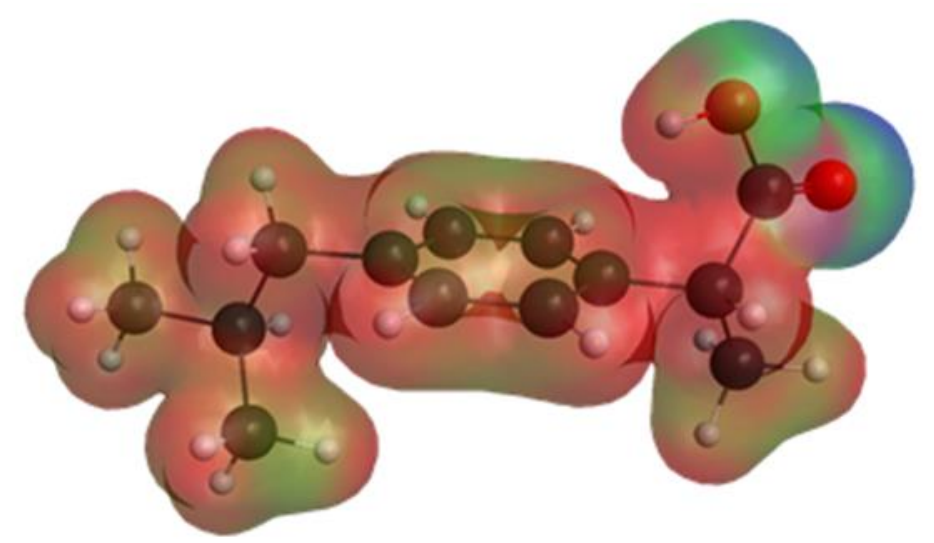

Figure 3 The calculated total elektron density of ibuprofen.

The Lowest Unoccupied Molecular Orbital (LUMO) and the Highest Occupied Molecular Orbital (LUMO) of ibuprofen has given in Figure-4. 

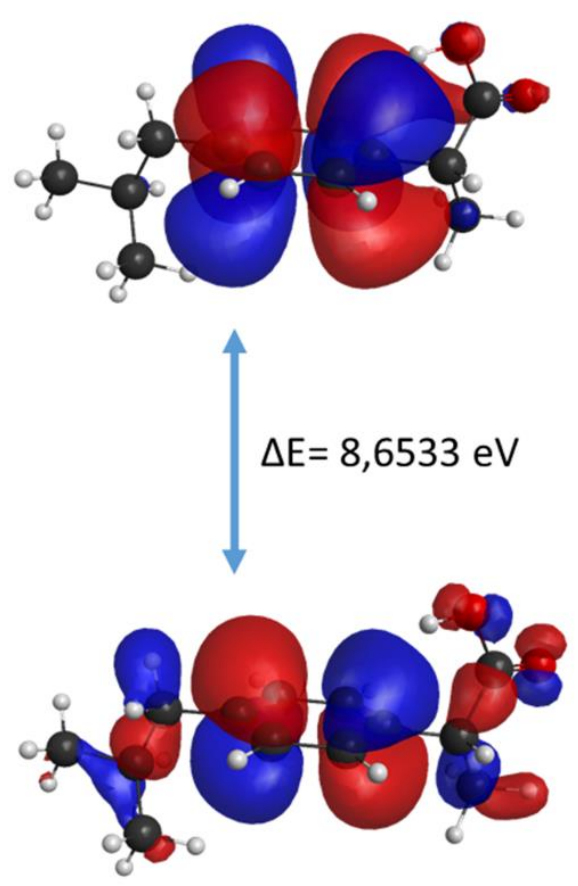

Figure 4 The Lowest Unoccupied Molecular Orbital (LUMO) and the Highest Occupied Molecular Orbital (LUMO) of ibuprofen.

At firs stage, ibuprofen had optimized by adding no polarisation function at all, as usually done in typical calculations. The calculated bond lengths and the X-RAY data (Derollez et al., 2010) have given in Table-1. A comparison graphic of the differences between calculated bond lengths and the X-RAY data can be seen in Figure-5.

\begin{tabular}{|c|c|c|c|c|}
\hline Atom1 & Atom2 & Length X-RAY (§̊) & $\begin{array}{l}\text { Length Calculated }(\AA) \\
\text { with no polarisation function }\end{array}$ & Difference $|\%|$ \\
\hline $\mathrm{C} 3$ & $\mathrm{C} 1$ & 1,510 & 1,521 & 0,728 \\
\hline C9 & $\mathrm{C} 10$ & 1,380 & 1,414 & 2,464 \\
\hline C13 & C11 & 1,510 & 1,547 & 2,450 \\
\hline $\mathrm{C} 11$ & $\mathrm{C} 12$ & 1,490 & 1,540 & 3,356 \\
\hline $\mathrm{C} 1$ & $\mathrm{C} 2$ & 1,550 & 1,552 & 0,129 \\
\hline $\mathrm{C} 10$ & C3 & 1,380 & 1,414 & 2,464 \\
\hline $\mathrm{C} 2$ & $\mathrm{C} 4$ & 1,520 & 1,541 & 1,382 \\
\hline $\mathrm{C} 2$ & $\mathrm{C5}$ & 1,530 & 1,541 & 0,719 \\
\hline $\mathrm{C} 3$ & C6 & 1,380 & 1,420 & 2,899 \\
\hline $\mathrm{C} 8$ & $\mathrm{C7}$ & 1,380 & 1,420 & 2,899 \\
\hline C6 & C7 & 1,380 & 1,408 & 2,029 \\
\hline C11 & $\mathrm{C} 8$ & 1,480 & 1,530 & 3,378 \\
\hline $\mathrm{C} 8$ & C9 & 1,380 & 1,414 & 2,464 \\
\hline $\mathrm{C2}$ & H1 & $\mathbf{0 , 9 8 3}$ & 1,115 & 13,428 \\
\hline $\mathrm{C1}$ & H10 & $\mathbf{0 , 9 5 0}$ & 1,112 & 17,053 \\
\hline $\mathrm{C1}$ & H11 & 1,010 & 1,113 & 10,198 \\
\hline $\mathrm{C4}$ & H12 & 1,010 & 1,114 & 10,297 \\
\hline $\mathrm{C4}$ & H13 & $\mathbf{0 , 9 8 0}$ & 1,113 & 13,571 \\
\hline $\mathrm{C4}$ & H14 & 0,980 & 1,113 & 13,571 \\
\hline C5 & H15 & 1,120 & 1,115 & $-0,446$ \\
\hline C5 & H16 & $\mathbf{0 , 9 8 0}$ & 1,112 & 13,469 \\
\hline C5 & H17 & 1,070 & 1,113 & 4,019 \\
\hline 02 & H18 & 1,068 & 0,983 & $-7,959$ \\
\hline \begin{tabular}{|l|}
$\mathrm{C10}$ \\
\end{tabular} & $\mathrm{H} 2$ & 0,990 & 1,106 & 11,717 \\
\hline \begin{tabular}{|l|}
$\mathrm{C} 9$ \\
\end{tabular} & H3 & 1,000 & 1,107 & 10,700 \\
\hline C6 & H4 & 0,990 & 1,107 & 11,818 \\
\hline $\mathrm{C7}$ & H5 & $\mathbf{0 , 9 8 0}$ & 1,107 & 12,959 \\
\hline C11 & H6 & 1,014 & 1,113 & 9,763 \\
\hline $\mathrm{C} 12$ & H7 & 1,050 & 1,112 & 5,905 \\
\hline C12 & H8 & $\mathbf{0 , 9 5 0}$ & 1,110 & 16,842 \\
\hline C12 & H9 & $\mathbf{0 , 9 7 0}$ & 1,111 & 14,536 \\
\hline C13 & O1 & 1,210 & 1,215 & 0,413 \\
\hline C13 & $\mathrm{O} 2$ & 1,280 & 1,365 & 6,641 \\
\hline
\end{tabular}


Table-1 The calculated bond lengths and the X-RAY data of ibuprofen, with differences.

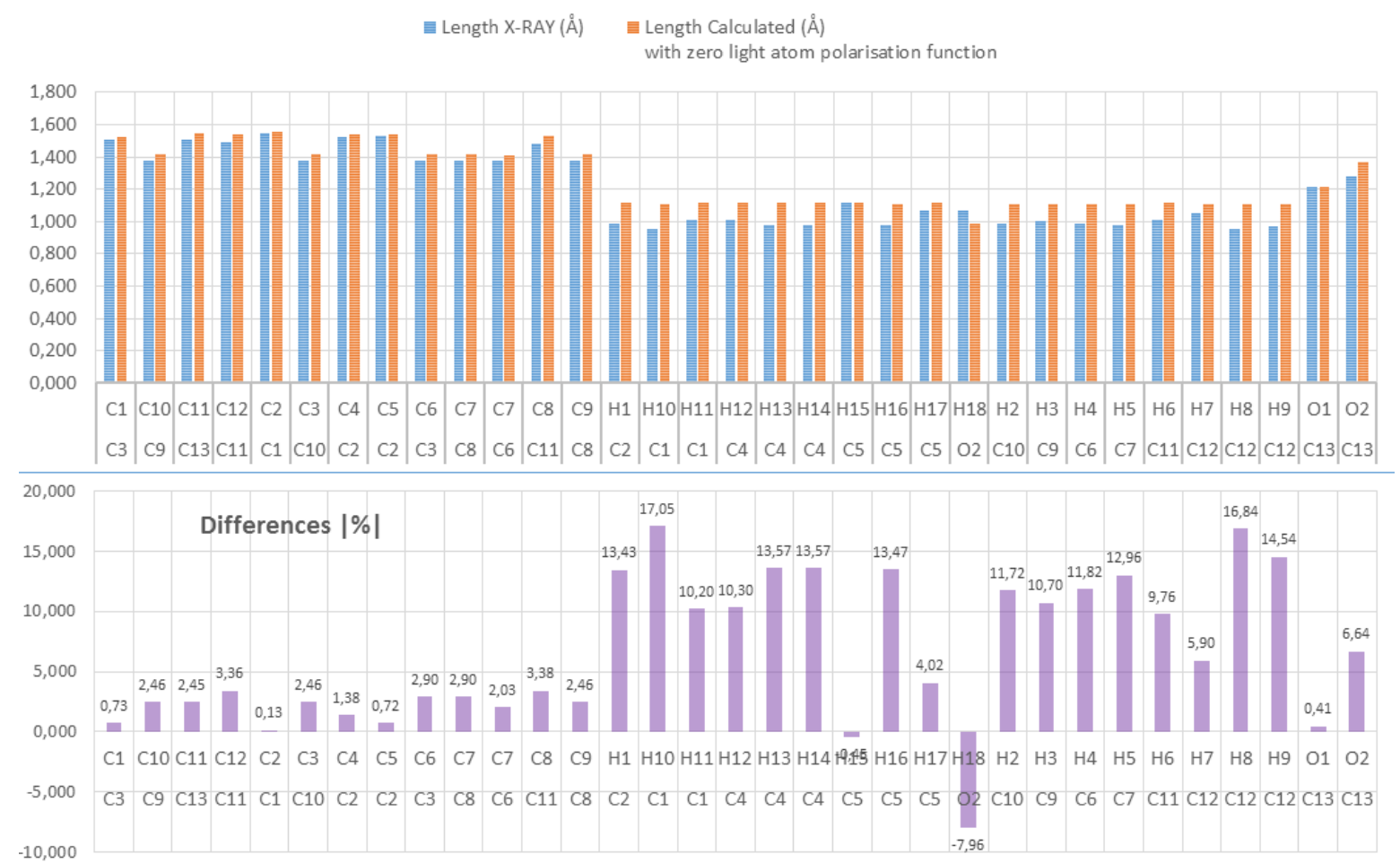

Figure 5 Comparison of the calculated bond lengths and the X-RAY data for ibuprofen.

$\mathrm{s}$ it is seen in table-1 and Figure-5, errors for the bonds, which Hydrogen included, are found within within 14-16\% range, while others found within only within $2-3 \%$ range. To see the effect of adding polarisation functions on to errors, we were repeated the optimisation calculation with exactly same starting configuration, also with same hardware, same software, and same parameters. But this time we added a polarisation function. The obtained results with a polarisation function have given in Table-2.

\begin{tabular}{|c|c|c|c|c|c|c|}
\hline Atom1 & Atom2 & $\begin{array}{c}\text { Length } \\
\text { X-RAY } \\
(\AA)\end{array}$ & $\begin{array}{l}\text { Length } \\
\text { Calculated } \\
\text { with no } \\
\text { polarisation } \\
\text { function (Å) }\end{array}$ & $\begin{array}{c}\text { Difference } \\
\text { with no } \\
\text { polarisation } \\
\text { function |\%| }\end{array}$ & $\begin{array}{l}\text { Difference } \\
\text { with a } \\
\text { polarisation } \\
\text { function (\%) }\end{array}$ & $\begin{array}{c}\text { Length } \\
\text { Calculated } \\
\text { with a } \\
\text { polarisation } \\
\text { function }(\AA \AA) \\
\end{array}$ \\
\hline C3 & $\mathrm{C} 1$ & 1,510 & 1,521 & 0,728 & 0,728 & 1,521 \\
\hline $\mathrm{CP}$ & C10 & 1,380 & 1,414 & 2,464 & 2,464 & 1,414 \\
\hline C13 & C11 & 1,510 & 1,547 & 2,450 & 2,450 & 1,547 \\
\hline C11 & C12 & 1,490 & 1,540 & 3,356 & 3,356 & 1,540 \\
\hline $\mathrm{C} 1$ & $\mathrm{C} 2$ & 1,550 & 1,552 & 0,129 & 0,129 & 1,552 \\
\hline C10 & C3 & 1,380 & 1,414 & 2,464 & 2,464 & 1,414 \\
\hline $\mathrm{C} 2$ & $\mathrm{C} 4$ & 1,520 & 1,541 & 1,382 & 1,382 & 1,541 \\
\hline $\mathrm{C} 2$ & $\mathrm{C} 5$ & 1,530 & 1,541 & 0,719 & 0,654 & 1,540 \\
\hline $\mathrm{C3}$ & C6 & 1,380 & 1,420 & 2,899 & 2,899 & 1,420 \\
\hline $\mathrm{C} 8$ & $\mathrm{C} 7$ & 1,380 & 1,420 & 2,899 & 2,899 & 1,420 \\
\hline C6 & $\mathrm{C7}$ & 1,380 & 1,408 & 2,029 & 2,029 & 1,408 \\
\hline C11 & C8 & 1,480 & 1,530 & 3,378 & 3,311 & 1,529 \\
\hline C8 & C9 & 1,380 & 1,414 & 2,464 & 2,464 & 1,414 \\
\hline
\end{tabular}


Avrupa Bilim ve Teknoloji Dergisi

\begin{tabular}{|c|c|c|c|c|c|c|}
\hline C2 & H1 & 0,983 & 1,115 & 13,428 & 13,123 & 1,112 \\
\hline C1 & H10 & 0,950 & 1,112 & 17,053 & 16,842 & 1,11 \\
\hline C1 & H11 & 1,010 & 1,113 & 10,198 & 9,901 & 1,11 \\
\hline C4 & H12 & 1,010 & 1,114 & 10,297 & 10,109 & 1,1121 \\
\hline C4 & H13 & 0,980 & 1,113 & 13,571 & 13,357 & 1,1109 \\
\hline C4 & H14 & 0,980 & 1,113 & 13,571 & 13,367 & 1,111 \\
\hline C5 & H15 & 1,120 & 1,115 & $-0,446$ & $-0,625$ & 1,113 \\
\hline C5 & H16 & 0,980 & 1,112 & 13,469 & 13,163 & 1,109 \\
\hline C5 & H17 & 1,070 & 1,113 & 4,019 & 3,364 & 1,106 \\
\hline O2 & H18 & 1,068 & 0,983 & $-7,959$ & $-8,146$ & 0,981 \\
\hline C10 & H2 & 0,990 & 1,106 & 11,717 & 11,515 & 1,104 \\
\hline C9 & H3 & 1,000 & 1,107 & 10,700 & 10,500 & 1,105 \\
\hline C6 & H4 & 0,990 & 1,107 & 11,818 & 11,616 & 1,105 \\
\hline C7 & H5 & 0,980 & 1,107 & 12,959 & 12,755 & 1,105 \\
\hline C11 & H6 & 1,014 & 1,113 & 9,763 & 9,566 & 1,111 \\
\hline C12 & H7 & 1,050 & 1,112 & 5,905 & 5,619 & 1,109 \\
\hline C12 & H8 & 0,950 & 1,110 & 16,842 & 16,526 & 1,107 \\
\hline C12 & H9 & 0,970 & 1,111 & 14,536 & 14,330 & 1,109 \\
\hline C13 & O1 & 1,210 & 1,215 & 0,413 & 0,413 & 1,215 \\
\hline C13 & O2 & 1,280 & 1,365 & 6,641 & 6,484 & 1,363 \\
\hline
\end{tabular}

Table-2 The calculated bond lengths with no polarisation function, also with one polarisation function and the X-RAY data of ibuprofen, comparatively.

The effect of adding a polarisation function to the calculation can be seen in Figure-6 comparatively.

Comparison of X-RAYdata and Calculated Bond Lengths

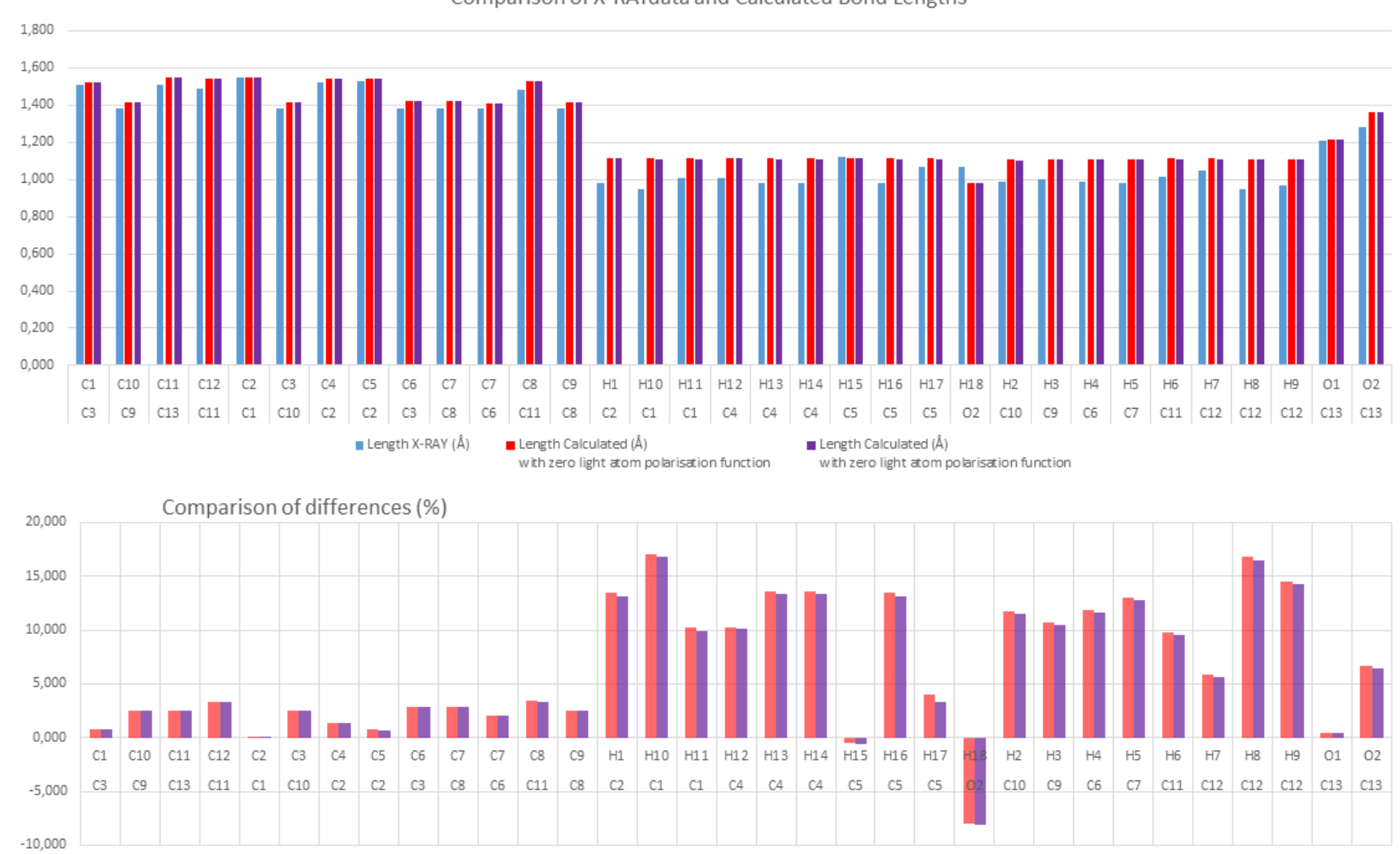

Figure 6 Comparison of the X-RAY data, calculated bond lengths with no polarisation function, and calculated bond lengths with a polarisation function. 
The changes of calculation errors after adding a polarisation function have given in Figure-7. As it is obviously seen in Figure-7, the added polarisation function especially effected to Hydrogen bonds, just as desired.

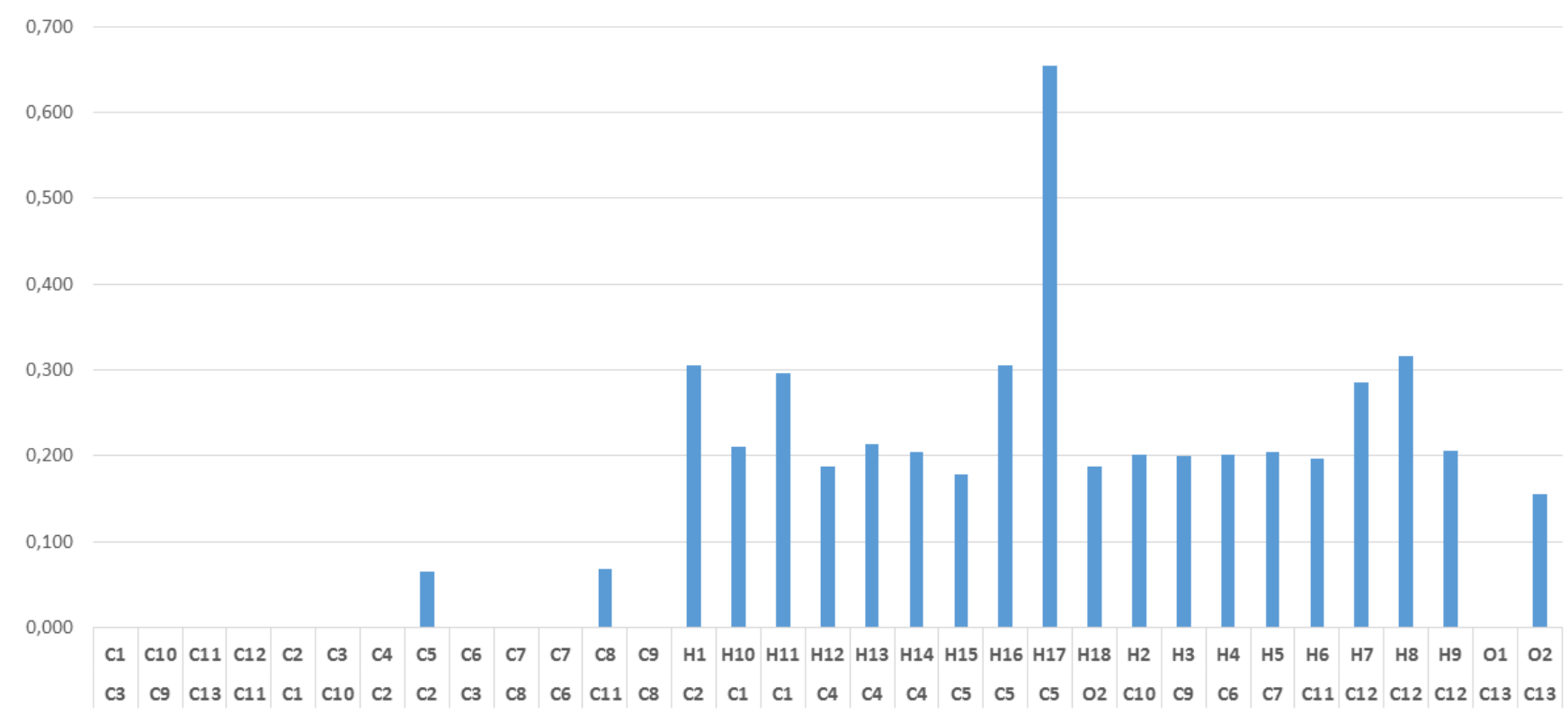

Figure 7 Changes of calculation errors after adding a polarisation function.

As it can be seen in Figure- 6 and Figure-7, adding a polarisation function reduced the errors. This decrement has occurred especially for the $\mathrm{H}$ bonds, just as we aimed. The other bonds had not been affected by the added polarisation function as much as $\mathrm{H}$ bonds did. This is what we have expected. Hence, this might be considered a clue for the truthness of our assumption, about the origin of the big calculation errors about hydrogens. However, although the the results have pointed out that we are on the right way, the strength of actual decrease of the errors have found far below the expectations.

To get more decrement about calculation errors of $\mathrm{H}$ bonds, 3 polarisation functions were added to the calculations, instead of just one. The obtained results have given in Table-3.

\begin{tabular}{|c|c|c|c|c|c|c|c|c|}
\hline Atom1 & Atom2 & $\begin{array}{c}\text { Length } \\
\text { X-RAY } \\
(\AA \AA)\end{array}$ & $\begin{array}{c}\text { Length } \\
\text { Calculated } \\
\text { with no } \\
\text { polarisation } \\
\text { function }(\AA)\end{array}$ & $\begin{array}{c}\text { Difference with } \\
\text { no polarisation } \\
\text { function }|\%|\end{array}$ & $\begin{array}{c}\text { Length } \\
\text { Calculated } \\
\text { with a } \\
\text { polarisation } \\
\text { function (Å) }\end{array}$ & $\begin{array}{l}\text { Difference with } \\
\text { a polarisation } \\
\text { function (\%) }\end{array}$ & $\begin{array}{c}\text { Length } \\
\text { Calculated } \\
\text { with athree } \\
\text { polarisation } \\
\text { functions (Å) }\end{array}$ & $\begin{array}{c}\text { Difference with } \\
\text { three polarisation } \\
\text { functions (\%) }\end{array}$ \\
\hline C3 & C1 & 1,510 & 1,521 & 0,728 & 1,521 & 0,728 & 1,518 & 0,530 \\
\hline C9 & C10 & 1,380 & 1,414 & 2,464 & 1,414 & 2,464 & 1,412 & 2,319 \\
\hline $\mathrm{C} 13$ & C11 & 1,510 & 1,547 & 2,450 & 1,547 & 2,450 & 1,548 & 2,517 \\
\hline C11 & $\mathrm{C} 12$ & 1,490 & 1,540 & 3,356 & 1,540 & 3,356 & 1,539 & 3,289 \\
\hline $\mathrm{C} 1$ & $\mathrm{C} 2$ & 1,550 & 1,552 & 0,129 & 1,552 & 0,129 & 1,55 & 0,000 \\
\hline C10 & C3 & 1,380 & 1,414 & 2,464 & 1,414 & 2,464 & 1,411 & 2,246 \\
\hline $\mathrm{C} 2$ & $\mathrm{C4}$ & 1,520 & 1,541 & 1,382 & 1,541 & 1,382 & 1,538 & 1,184 \\
\hline $\mathrm{C} 2$ & $\mathrm{C} 5$ & 1,530 & 1,541 & 0,719 & 1,540 & 0,654 & 1,538 & 0,523 \\
\hline $\mathrm{C} 3$ & C6 & 1,380 & 1,420 & 2,899 & 1,420 & 2,899 & 1,417 & 2,681 \\
\hline $\mathrm{C} 8$ & $\mathrm{C} 7$ & 1,380 & 1,420 & 2,899 & 1,420 & 2,899 & 1,416 & 2,609 \\
\hline $\mathrm{C6}$ & $\mathrm{C} 7$ & 1,380 & 1,408 & 2,029 & 1,408 & 2,029 & 1,406 & 1,884 \\
\hline C11 & $\mathrm{C} 8$ & 1,480 & 1,530 & 3,378 & 1,529 & 3,311 & 1,526 & 3,108 \\
\hline $\mathrm{C} 8$ & $\mathrm{C9}$ & 1,380 & 1,414 & 2,464 & 1,414 & 2,464 & 1,41 & 2,174 \\
\hline C2 & H1 & 0,983 & 1,115 & 13,428 & 1,112 & 13,123 & 1,113 & 13,225 \\
\hline
\end{tabular}




\begin{tabular}{|l|c|c|c|c|c|c|c|c|}
\hline C1 & H10 & 0,950 & 1,112 & 17,053 & 1,11 & 16,842 & 1,109 & 16,737 \\
\hline C1 & H11 & 1,010 & 1,113 & 10,198 & 1,11 & 9,901 & 1,109 & 9,802 \\
\hline C4 & H12 & 1,010 & 1,114 & 10,297 & 1,1121 & 10,109 & 1,111 & 10,000 \\
\hline C4 & H13 & 0,980 & 1,113 & 13,571 & 1,1109 & 13,357 & 1,109 & 13,163 \\
\hline C4 & H14 & 0,980 & 1,113 & 13,571 & 1,111 & 13,367 & 1,109 & 13,163 \\
\hline C5 & H15 & 1,120 & 1,115 & $-0,446$ & 1,113 & $-0,625$ & 1,112 & $-0,714$ \\
\hline C5 & H16 & 0,980 & 1,112 & 13,469 & 1,109 & 13,163 & 1,108 & 13,061 \\
\hline C5 & H17 & 1,070 & 1,113 & 4,019 & 1,106 & 3,364 & 1,109 & 3,645 \\
\hline O2 & H18 & 1,068 & 0,983 & $-7,959$ & 0,981 & $-8,146$ & 0,981 & $-8,146$ \\
\hline C10 & H2 & 0,990 & 1,106 & 11,717 & 1,104 & 11,515 & 1,1 & 11,111 \\
\hline C9 & H3 & 1,000 & 1,107 & 10,700 & 1,105 & 10,500 & 1,102 & 10,200 \\
\hline C6 & H4 & 0,990 & 1,107 & 11,818 & 1,105 & 11,616 & 1,101 & 11,212 \\
\hline C7 & H5 & 0,980 & 1,107 & 12,959 & 1,105 & 12,755 & 1,1 & 12,245 \\
\hline C11 & H6 & 1,014 & 1,113 & 9,763 & 1,111 & 9,566 & 1,111 & 9,566 \\
\hline C12 & H7 & 1,050 & 1,112 & 5,905 & 1,109 & 5,619 & 1,108 & 5,524 \\
\hline C12 & H8 & 0,950 & 1,110 & 16,842 & 1,107 & 16,526 & 1,106 & 16,421 \\
\hline C12 & H9 & 0,970 & 1,111 & 14,536 & 1,109 & 14,330 & 1,108 & 14,227 \\
\hline C13 & O1 & 1,210 & 1,215 & 0,413 & 1,215 & 0,413 & 1,216 & 0,496 \\
\hline C13 & O2 & 1,280 & 1,365 & 6,641 & 1,363 & 6,484 & 1,36 & 6,250 \\
\hline
\end{tabular}

Table-3 The calculated bond lengths with no polarisation function, with a polarisation function, with three polarisation functions and the X-RAY data of ibuprofen, comparatively.

The effect of adding three polarisation functions to the calculation can be seen in Figure- 8 comparatively.
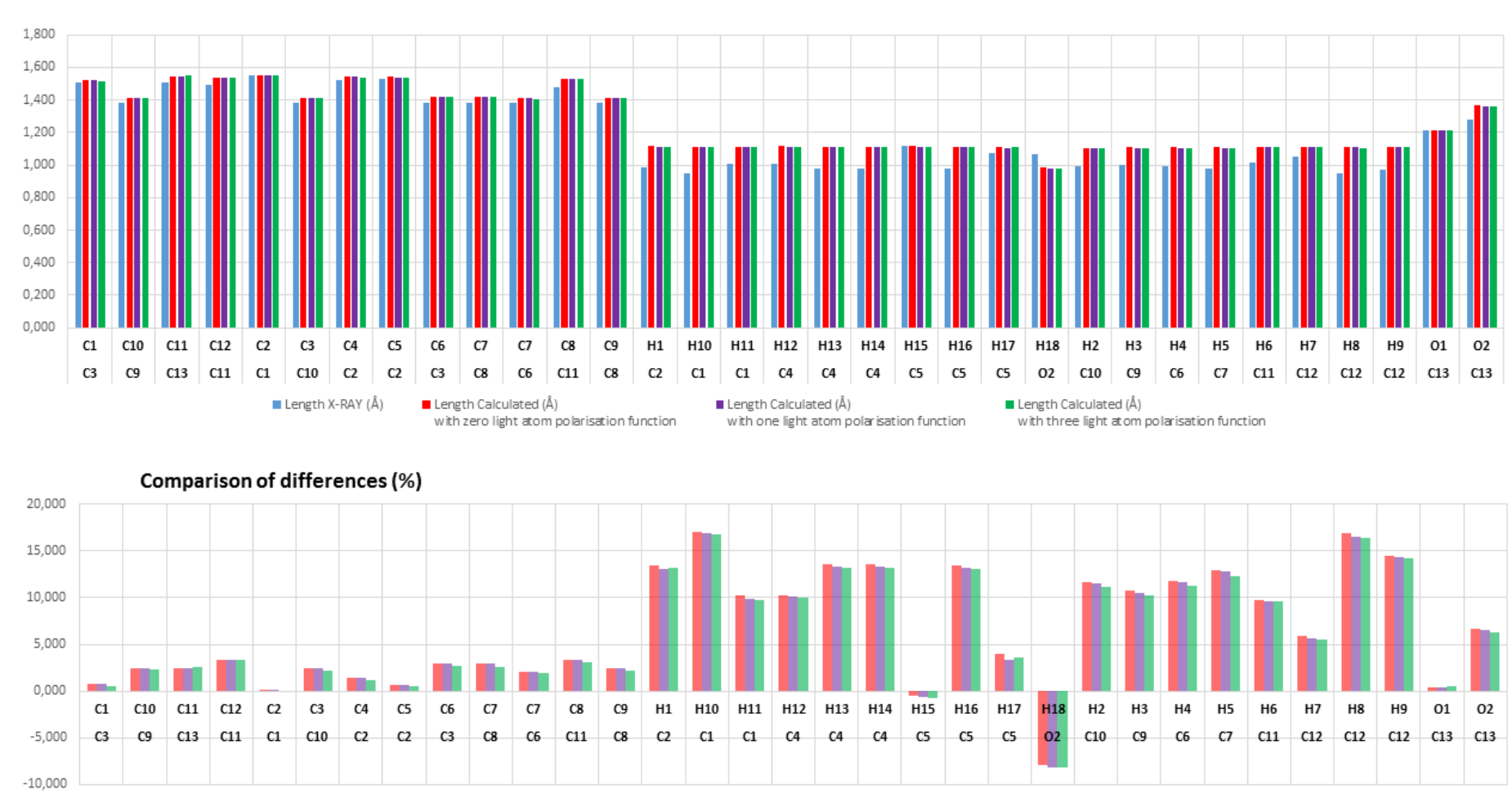

Figure 8 Comparison of the X-RAY data, the calculated bond lengths with no polarisation function, the calculated bond lengths with a polarisation function, and the calculated bond lengths with three polarisation functions. 
As it is seen in Figure-8, adding three polarisation functions hasn't changed the calculated bond profile much. Adding two more polarisation functions has changed error rates just a little bit, sometimes even it has increased the error rate itself.

On the other hand, adding more polarisation functions to calculations has some computational costs, as it is seen in Table-4.

\begin{tabular}{|l|c|c|c|}
\cline { 2 - 4 } \multicolumn{1}{c|}{} & $\begin{array}{l}\text { Number of polarisation } \\
\text { functions } \mathbf{= 0}\end{array}$ & $\begin{array}{l}\text { Number of polarisation } \\
\text { functions = 1 }\end{array}$ & $\begin{array}{l}\text { Number of polarisation } \\
\text { functions = 3 }\end{array}$ \\
\hline $\begin{array}{l}\text { TOTAL NUMBER OF BASIS SET } \\
\text { SHELLS }\end{array}$ & 81 & 99 & 135 \\
\hline $\begin{array}{l}\text { NUMBER OF CARTESIAN GAUSSIAN } \\
\text { BASIS FUNCTIONS }\end{array}$ & 246 & 300 & 408 \\
\hline
\end{tabular}

Table-4 Total number of basis set shells and number of Cartesian Gaussian basis functions for each calculation case.

As it is seen in Table-4, computational cost of calculations increased too much, according to the benefits of this cost in terms of decreasing calculation errors.

\section{Conclusions and Recommendations}

Although it is actually reduces the Hydrogene bond errors, it is not recommended to use "more polarisation functions", in order to minimise computational errors about these bonds. Because, using more polarisation functions, increases the computational cost, but this cost is not worth to outcome; a major increment in computational cost, gives only a fractrional improvement about eliminating $\mathrm{H}$ bond errors.

Also, it is proved that, the polarisation effect of hydrogen atoms is not the main reason of the relatively big calculation errors about bonds of hydrogen atoms.

\section{References}

Boese, A. D. (2015). Density Functional Theory and Hydrogen Bonds: Are We There Yet? ChemPhysChem, 16(5), 978-985. https://doi.org/10.1002/cphc.201402786

Derollez, P., Dudognon, E., Affouard, F., Danède, F., Correia, N. T., \& Descamps, M. (2010). Ab initio structure determination of phase II of racemic ibuprofen by X-ray powder diffraction. Acta Crystallographica Section B Structural Science, 66(1), 76-80. https://doi.org/10.1107/S0108768109047363

Dykstra, C., Frenking, G., \& Kim, K. (2011). Theory and Applications of Computational Chemistry: The First Forty Years. Retrieved from http://qut.eblib.com.au/patron/FullRecord.aspx?p=269993

Hohenberg, P., \& Kohn, W. (1964). Inhomogeneous Electron Gas. Physical Review, 136(3B), B864-B871. https://doi.org/10.1103/PhysRev.136.B864

Ireta, J., Neugebauer, J., \& Scheffler, M. (2004). On the Accuracy of DFT for Describing Hydrogen Bonds: Dependence on the Bond Directionality. The Journal of Physical Chemistry A, 108(26), 5692-5698. https://doi.org/10.1021/jp0377073

Rozas, I. (2007). On the nature of hydrogen bonds: An overview on computational studies and a word about patterns. Physical Chemistry Chemical Physics, 9(22), 2782. https://doi.org/10.1039/b618225a

Schmidt, M. W., Baldridge, K. K., Boatz, J. A., Elbert, S. T., Gordon, M. S., Jensen, J. H., ... Montgomery, J. A. (1993). General atomic and molecular electronic structure system. Journal of Computational Chemistry, 14(11), 1347-1363. https://doi.org/10.1002/jcc.540141112

Stevens, W. J., Krauss, M., Basch, H., \& Jasien, P. G. (1992). Relativistic compact effective potentials and efficient, shared-exponent basis sets for the third-, fourth-, and fifth-row atoms. Canadian Journal of Chemistry, 70(2), 612-630. https://doi.org/10.1139/v92-085

Yanai, T., Tew, D. P., \& Handy, N. C. (2004). A new hybrid exchange-correlation functional using the Coulomb-attenuating method (CAM-B3LYP). Chemical Physics Letters, 393(1-3), 51-57. https://doi.org/10.1016/j.cplett.2004.06.011 